\title{
Pengaruh Biaya Pemeliharaan dan Harga Jual terhadap Pendapatan
}

\section{(Studi Kasus Pada PT. Perindustrian dan Perdagangan Lembah Karet)}

\author{
Maratul Jannah', Muhammad Rivandi ${ }^{2}$ \\ ${ }^{1,2}$ Sekolah Tinggi Ilmu Ekonomi KBP \\ Email : $\underline{\text { Maratulana213@gmail.com }}$ \\ ²Muhammadrivandi@akbpstie.ac.id
}

\begin{abstract}
Income is the main aspect in financial statements and used as one of measurements for managing the company. This is aim to know the cost effect in maintenance and selling price to income. The research is use quantitative method. The object of the research is the rubber's industry and trading company in 2006 to 2016. Because of limited data collection, the analysis method is using statistic non parametric with spearman's test correlation. The result of the test showed that the cost of the maintenance does not have correlation with income. Besides, the selling price has the positive correlation with income.
\end{abstract}

Key words : maintenance cost, selling price and income

\section{PENDAHULUAN}

Pada umumnya pendapatan merupakan unsur utama dalam laporan keuangan dan digunakan sebagai salah satu ukuran untuk mengetahui sejauh mana kinerja manajemen dalam mengelola perusahaan. Tujuan utama perusahaan adalah untuk memperoleh pendapatan yang memadai yang sesuai dengan jumlah investasi yang ditanamkan untuk menghasilkan produk dan jasa, sesuai dengan pertumbuhan jangka panjang.

Menurut Kusnadi (2000) Pendapatan merupakan penambahan aktiva yang dapat mengakibatkan bertambahnya modal namun bukan dikarenakan penambahan modal dari pemilik atau hutang melainkan melalui penjulan barang atau jasa terhadap pihak lain. Hal ini sangat berpengaruh terhadap kelangsungan hidup perusahaan, semakin besar pendapatan yang diperoleh maka semakin besar kemampuan perusahaan untuk membiayai segala pengeluaran dan biaya pemeliharaan atas barangbarang diperusahaan tersebut. Pendapatan yang diperoleh perusahaan tidak lepas dari pengaruh harga jual yang diberikan perusahaan terhadap produk yang akan mereka pasarkan. Semakin murah harga suatu barang maka permintaan akan barang tersebut 
akan meningkat. Dengan demikian, pengembangan suatu usaha perlu didukung oleh penentuan seberapa besar biaya yang dikeluarkan pada saat produksi.

Konsep pembentukan pendapatan menyatakan bahwa pendapatan terbentuk, terhimpun, atau terhak (to be earned) bersamaan dengan melekat pada seluruh atau totalitas proses berlangsungnya operasi perusahaan dan bukan sebagai hasil transaksi tertentu. Dengan kata lain, sebelum penjualan terjadi, pendapatan dianggap sudah terbentuk seiring dengan berjalannya operasi perusahaan (Suwardjono, 2010). Berdasarkan konsep pembentukan pendapatan maka diperlukan pecatatan pendapatan. Metode pencatatan terdiri dari metode Cash basis dan Accrual basis. Cash basis adalah sistem dimana pendapatan belum diakui sebelum pendapatan tersebut diterima. Sedangkan Acrrual basis adalah dimana pendapatan dicatat pada saat sudah terjadi hak tanpa memperhatikan pendapatan tersebut diterima.

Peneliti tertarik meneliti pada PT. Perindustrian dan Perdagangan Lembah Karet karena peneliti melihat terjadinya penurunan pendapatan yang sangat signifikan di PT. Perindustrian dan Perdagangan Lembah karet dan hasil peneliti terdahulu yang berbeda.

Pendapatan menurut Kusnadi (2000) pendapatan merupakan penambahan aktiva yang dapat mengakibatkan bertambahnya modal namun bukan dikarenakan penambahan modal dari pemilik atau hutang melainkan melalui penjualan barang dan atau jasa terhadap pihak lain.

Konsep pembentukan pendapatan menyatakan bahwa pendapatan terbentuk, terhimpun, atau terhak (to be earned) bersamaan dengan dan meleket pada seluruh atau totalitas proses berlangsungnya operasi perusahaan dan bukan sebagai hasil transaksi tertentu. Dengan kata lain, sebelum penjualan terjadi, pendapatan dianggap sudah terbentuk seiring dengan berjalannya operasi perusahaan. Operasi perusahaan meliputi kegiatan produksi, penjualan, dan pengumpulan piutang. Konsep pembentukan ini sering disebut pendekatan proses pembentukan pendapatan pendekatan kegiatan (Suwardjono, 2010)

Metode dalam pencatatan terdiri dari dua metode, yaitu sebagai berikut Rumahorbo (2006): a) Metode Cash Basis Suatu sistem dimana pendapatan belum diakui sebelum pendapatan tersebut belum diterima. Metode ini banyak digunakan pada perusahaan kecil dan orang-orang menjual jasa, pada umumnya adalah orangorang yang memiliki keahlian tertentu. b) Metode A ccrual BasisMetode pencatatan pendapatan, dimana pendapatan itu dicatat pada saat sudah terjadi hak tanpa memperhatikan pendapatan tersebut diterima. Keuntungan metode ini adalah karena metode ini sangat teliti dalam pengukuran keuntungan(dalam laporan laba rugi) dan neraca selisih.

Pemeliharaan adalah suatu kombinasi dari berbagai tindakan yang dilakukan untuk menjaga suatu barang, atau memperbaikinya sampai suatu kondisi yang bisa diterima (Setiawan, 2008). Pemeliharaan mempunyai peran yang sangat penting dalam menentukan kegiatan proses produksi disuatu perusahaan, karna aktivitas pemeliharaan juga menentukan tingkat kelancaran dan efisiensi produksi. 
Berbagai metode untuk mengestimasi anggaran pemeliharaan yang umum digunakan adalah sebagai berikut (Rumahorbo, 2006) : a)Actual Expenditure, b) Repair-Cost Rate Method, c) Unit-Cost Rate Method, d) Zero-Base Method, e) Mixed method.

Harga jual adalah besarnya harga yang akan dibebankan kepada konsumen yang diperoleh atau dihitung dari biaya produksi di tambah biaya nonproduksi dan laba yang diharapkan (Mulyadi 2005). Perusahaan biasanya berupaya menentukan harga yang akan memaksimalisasi nilai perusahaan. Harga yang ditentukan untuk sebuah produk akan mempengaruhi pendapatan perusahaan dan pada akhir keuntungannya. Mengingat bahwa pendapatan dari penjualan sebuah produk akan sama dengan harga dikalikan dengan kuantitas penjualan. Meskipun harga yang lebih rendah akan mengurangi pendapatan perunit yang diterima, biasanya akan menghasilkan kuantitas penjualan yang lebih tinggi. Harga yang lebih akan meningkatkan pendapatan perunit yang diterima namun akan meningkatkan pendapatan perunit yang diterima namun akan menghasilkan kuantitas unit penjualan yang lebih rendah.

Menurut Pahan (2010) lancar atau tidaknya suatu usaha bergantung kepada biaya yang dikeluarkan, biaya produksi sebagai penunjang segala aktivitas yang ada karena menyangkut dengan produktivitas tanaman dan keuntungan bagi petani, selain itu biaya yang diusahakan juga harus diperhitungkan, karna biaya yang dikeluarkan akan menurunkan pendapatan.

Menurut Crisdandi (2015) dan Nugraha (2012) menemukan bahwa biaya pemeliharaan berpengaruh negatif signifikan terhadap pendapatan. Apabila terdapat peningkatan biaya pemeliharaan maka akan menyebabkan pendapatan operasional meningkat. semakin naik biaya pemeliharaan akan diikuti dengan kenaikan pendapatan operasional perusahaan. Berdasarkan teori diatas dan penelitian terdahulu maka dapat diturunkan hipotesis yang akan dibuktikan secara empiris

\section{$\mathrm{H}_{1}$ : Biaya Pemeliharaan berpengaruh Negatif terhadap Pendapatan}

Menurut Fandy (2005) harga jual merupakan satuan moneter atau ukuran lainnya (termasuk barang dan jasa lainnya) yang ditukar agar memperoleh hak kepemilikan atau penggunaan suatu barang atau jasa yang akan berpengaruh langsung terhadap laba perusahaan.

Penelitian yang dilakukan Rasyid, Kasim, \& Kurniawan (2012) dan Crisdandi (2015) menyatakan bahwa harga jual berpengaruh positif terhadap pendapatan. Dikarenakan jika harga jual suatu produk naik maka pendapatan perusahaan juga akan naik. Harga jual mempengaruhi pendapatan penjualannya.Permintaan konsumen yang meningkat yang menyebabkan harga jual meningkat. Harga jual yang meningkat maka memberikan keuntungan yang tinggi kepada pedagang 
Harga jual suatu produk sangat berkaitan dengan pendapatan. Harga jual produk akan menambah pendapatan usaha, secara teori semakin tinggi harga jual semakin tinggi pendapatan, tinggi harga jual tinggi disebabkan karena permintaan konsumen yang tinggi. Berdasarkan teori dan penelitian terdahulu maka dapat diturunkan hipotesis yang akan dibuktikan secara empiris.

\section{$\mathrm{H}_{2}$ : Harga jual berpengaruh positif terhadap pendapatan.}

\section{METODE PENELITIAN}

Pada penelitian ini penulis memilih jenis penelitian kuantitatif. Penelitian kuantitatif merupakan metode ilmiah karena telah memenuhi kaidah-kaidah ilmiah yaitu konkrit/empiris, objektif, terukur, rasional dan sistematik. Dan juga disebut metode kuantitatif karena data pada penelitian berupa angka-angka dan analisis menggunakan statistik (Sugiyono, 2015). Pada penelitian ini bertujuan untuk meneliti pengaruh biaya pemeliharaan dan harga jual terhadap pendapatan di PT. Perindustrian dan Perdagangan Lembah Karet.

Jenis data didalam penelitian ini adalah time series. Pengukuran yang digunakan dalam time series adalah data rasio. Dimana data rasio merupakan merupakan data tentang keterangan yang memberikan nilai yang diukur dari nilai absolut. Sumber data penelitian ini mengambil laporan keuangan pada PT. Perindustrian dan Perdagangan Lembah Karet.

Teknik pengumpulan data yang dipakai dalam penelitian ini adalah metode dokumentasi pengumpulan data dengan pengamatan, dimana peneliti tidak terlibat langsung dalam aktivitas tapi hanya sebagai pengamat independen. Dokumentasi data didalam penelitian dengan mengumpulkan laporan keuangan PT. Perindustrian dan Perdagangan Lembah Karet Padang dari tahun 2006 sampai tahun 2016. Dimana dari data laporan keuangan yang diambil yaitu biaya pemeliharaan, harga jual dan pendapatan.

\section{Defenisi Operasional Variabel}

Biaya pemeliharaan adalah suatu kombinasi dari berbagai tindakan yang dilakukan untuk menjaga suatu barang, atau memperbaikinya sampai suatu kondisi yang bisa diterima (Setiawan, 2008). Pengukuran Biaya pemeliharaan = biaya pemeliharaan bangunan \& inventaris, biaya pemeliharaan peralatan, biaya pemeliharaan kendraan (Crisdandi, 2015).

Harga jual adalah besarnya harga yang akan dibebankan kepada konsumen yang diperoleh atau dihitung dari biaya produksi di tambah biaya nonproduksi dan laba yang diharapkan (Mulyadi, 2005). Pengukurannya yaitu Harga jual = harga jual karet dalam satuan Ton (Crisdandi, 2015). pendapatan adalah pendapatan yang diterima perusahaan yang ada kaitan langsung dengan usaha pokok perusahaan 
(Kusnadi, 2000). Pengukurannya yaitu Pendapatan = Jumlah Pendapatan (Crisdandi, 2015).

Dikarenakan keterbatasan data yang diperoleh dari perusahaan, maka digunakan uji statistik non parametrik yaitu uji spearman test korelasi. Dimana tujuan dari menggunakan uji ini untuk mengatahui korelasi hubungan antara dua variabel.

Teknik analisis data yang dipakai dalam penelitian ini adalah non parametrik. Statistik non parametrik yaitu satistik bebas sebaran (tidak mensyaratkan bentuk sebaran parameter populasi, baik normal atau tidak) (Sugiyono, 2015). Selain itu, statistik non parametrik biasanya menggunakan skala pengukuran social, yakni nominal dan ordinal yang umumnya tidak berdistribusi normal. Statistik yang non parametrik yang dipakai adalah : analisis spearman test correlation. Spearman's Rho Korelasi digunakan untuk mengetahui korelasi dua variabel ditinjau dari peringkatnya, maksudnya yang dikorelasikan adalah peringkatnya, jadi sebelum melakukan korelasi menggunakan spearman, maka terlebih dahulu peneliti memeringkatkan data yang diperolah dari peringkat 1 hingga peringkat $\mathrm{n}$ berdasarkan data yang diperoleh (Djuniadi, Afiffudin, \& Lestari, 2016).

Hasil pengujian spearman dapat dikatakan berhubungan korelasi apabila nilai signifikansi $(2$-tailed $)<0,05$ sedangkan apabila nilai signifikansi $(2$-tailed $)>0,05$ maka tidak memiliki hubungan correlation.

\section{HASIL DAN PEMBAHASAN}

\section{Statistik deskriptif}

Tabel 2

\section{Hasil statistik deskriptif}

\begin{tabular}{|l|r|r|r|r|r|}
\hline \multicolumn{1}{|c|}{ Descriptive Statistics } \\
\hline biaya & $\mathrm{N}$ & \multicolumn{1}{c|}{ Minimum } & Maximum & \multicolumn{1}{c|}{ Mean } & \multicolumn{1}{c|}{ Std. Deviation } \\
pemeliharaan & 11 & 96389317.20 & 1381667028.00 & 854746409.2000 & 419922765.95103 \\
harga jual & 11 & 15641.79 & 36910.06 & 24918.8309 & 6504.00584 \\
Pendapatan & 11 & 385843497142. & 1091844096163. & 673332433532.4546 & 189652587284.029 \\
& 11 & 00 & 00 & & 50 \\
Valid N & & & & & \\
(listwise) & & & & & \\
\hline
\end{tabular}

Sumber :olah data statistik SPSS 23

Pada gambaran statistik deskriptif pada tabel 2 bahwa dapat dijelaskan bahwa data penelitian ini menggunakan data laporan keuangan tahunan PT. Perindustrian dan Perdagangan Lembah Karet padang selama sebelas tahun yaitu dari tahun 2006 sampai tahun 2016. Maka terdapat 11 sampel yang akan dilakukan pengujian. 
Nilai biaya pemeliharaan terendah yang dimiliki PT. perindustrian dan Perdagangan Lembah Karet adalah sebesar Rp. 96.389.317,20 sedangkan nilai biaya pemeliharaan tertinggi yang dimilki PT. Perindustrian dan Perdagangan Lembah Karet adalah sebesar Rp. 1.381.667.028. secara keseluruhan pada umumnya PT. Perindustrian dan Perdagangan Lembah karet yang digunakan dalam penelitian ini memiliki rata-rata biaya pemeliharaan sebesar Rp. 854.746.409,2000 yang menghasilkan standar deviasi sebesar Rp. 419.922.765,95103.

Nilai harga jual terendah yang dimilki PT. Perindustrian dan Perdagangan Lembah Karet adalah sebesar Rp. 15.641,79 sedangkan nilai harga jual tertinggi yang dimilki PT. Perindustrian dan Perdagangan Lembah Karet adalah sebesar Rp. 36.910,06. Secara keseluruhan pada umumnya PT. Perindustrian dan Perdagangan Lembah Karet yang digunakan dalam penelitian ini memiliki rata-rata Rp. 24.918,8309 yang menghasilkan standar deviasi sebesar Rp. 6504,00584.

Nilai pendapatan terendah yang dimiliki PT. Perindustrian dan Perdagangan Lembah Karet adalah sebesar Rp. 385.843.497.142 sedangkan pendapatn tertinggi yang dimiliki PT. Perindustrian dan Perdagangan Lembah Karet adalah sebesar Rp. 1.091.844.096.163 secara keseluruhan pada umumnya PT. Perindustrian dan Perdagangan Lembah Karet yang digunakan dalam penelitian ini memiliki rata-rata sebesar Rp. 673.332.433.532,4546 yang menghasilkan standar deviasi Rp. 189.652.587.584,02950.

\section{Pengujian Spearman's test}

Spearman's test Rho korelasi digunakan untuk mengetahui korelasi dua variabel ditinjau dari peringkatnya, maksudnya yang dikorelasikan adalah peringkatnya, jadi sebelum melakukan korelasi menggunakan spearman's, maka terlebih dahulu peneliti memeringkatkan data yang diperoleh dari peringkat 1 hingga peringkat ke $\mathrm{n}$ berdasarkan data yang diperoleh (Djuniadi et al., 2016).

Hasil pengujian spearman's dapat dikatakan berhubungan korelasi apabila nilai signifikansi $(2$-tailed $)<0,05$ sedangkan apabila nilai signifikansi (2-tailed) $>0,05$ maka tidak memiliki hubungan korelasi.

\section{Tabel 3}

\section{Hasil uji Spearman's test Rho Korelasi}

\begin{tabular}{|c|c|c|c|c|c|}
\hline \multicolumn{6}{|c|}{ Correlations } \\
\hline & & & $\begin{array}{c}\text { Biaya } \\
\text { pemeliharaan }\end{array}$ & harga jual & pendapatan \\
\hline \multirow[t]{9}{*}{ Spearman's rho } & \multirow{3}{*}{$\begin{array}{l}\text { Biaya } \\
\text { pemeliharaan }\end{array}$} & Correlation Coefficient & 1.000 & -.545 & -.527 \\
\hline & & Significance (2-tailed) & & .083 & .096 \\
\hline & & $\mathrm{N}$ & 11 & 11 & 11 \\
\hline & \multirow[t]{3}{*}{ harga jual } & Correlation Coefficient & -.545 & 1.000 & $.718^{*}$ \\
\hline & & Significance (2-tailed) & .083 & . & .013 \\
\hline & & $\mathrm{N}$ & 11 & 11 & 11 \\
\hline & \multirow[t]{3}{*}{ Pendapatan } & Correlation Coefficient & -.527 & $.718^{*}$ & 1.000 \\
\hline & & Significance (2-tailed) & .096 & .013 & $\cdot$ \\
\hline & & $\mathrm{N}$ & 11 & 11 & 11 \\
\hline
\end{tabular}

*. Corr. is significant at .05 level 2-tail... 
Berdasarkan tabel 3 dilihat model correlationspearman's test untuk variabel biaya pemeliharaan terhadap pendapatan diperoleh model correlation yang dihasilkan bernilai -0,527 dengan nilai sig (2-tailed) 0,096 >0,05. Hasil yang didapat menunjukan bahwa biaya pemeliharaan tidak memiliki hubungan yang signifikan terhadap pendapatan di PT. Perindustrian dan Perdagangan Lembah Karet.Kesimpulan hasil menunjukan bahwa biaya pemeliharaan tidak berpengaruh terhadap pendapatan tetapi dengan menggunakan uji spearman's test correlation biaya pemeliharaan tidak mempunyai hubungan dengan pendapatan di PT. Perindustrian dan perdagangan Lembah Karet.

Pada tabel 3 model correlationspearman's test untuk variabel harga jual terhadap pendapatan. Diperoleh model correlation yang dihasilkan bernilai $-0,718$ dengan nilai sig (2-tailed) $0,013<0,05$. Hasil yang didapat menunjukkan bahwa harga jual memiliki hubungan positif yang signifikan terhadap pendapatan di PT. Perindustrian dan perdaganagn Lembah Karet. Kesimpulan hasil menunjukan bahwa harga jual tidak berpengaruh terhadap pendapatan tetapi dengan menggunakan uji spearman's test correlation harga jual mempunyai hubungan positif dengan pendapatan di PT. Perindustrian dan Perdagangan Lembah Karet.

\section{PEMBAHASAN}

\section{Hubungan Biaya Pemeliharaan dengan pendapatan}

Pada tabel 3 manunjukkan bahwa biaya pemeliharaan tidak mempunyai hubungan dengan pendapatan di PT. Perindustrian dan Perdagangan Lembah Karet.

Biaya pemeliharaan menurut Setiawan (2008) adalah suatu kombinasi dari berbagai tindakan yang dilakukan untuk menjaga suatu barang, atau memperbaikinya sampai suatu kondisi yang bisa diterima. Pemeliharaan mempunyai peran yang sangat penting dalam kegiatan proses produksi pada suatu perusahaan, karena aktivitas pemeliharaan menentukan tingkat kelancaran dan efisiensi produksi.Menurut Pahan (2010) lancar atau tidaknya suatu usaha bergantung kepada biaya yang dikeluarkan, biaya produksi sebagai penunjang segala aktivitas yang ada, selain itu biaya yang diusahakan juga harus diperhitungkan. Tetapi didalam faktanya biaya pemeliharaan tidak berhubungan dengan pendapatan. Biaya yang dikeluarkan tidak ada berhubungan dengan pendapatan baik rendah atau tingginya biaya pemeliharaan yang dikeluarkan tidak mempengaruhi pendapatan.

Biaya pemeliharaan yang dilakukan perusahaan didanai dari modal perusahaan sehingga tidak mempengaruhi ke pendapatan, hal ini dilakukan untuk meningkatkan proses aktivitas produksi perusahaan di PT. Perindustrian dan Perdangan Lembah Karet.

Hal ini terbukti pada PT. Perindustrian dan Perdagangan Lembah Karet, dapat dilihat pada tahun 2009 biaya pemeliharaan yang dilakukan sebesar Rp. 1.252.946.822 namun pendapatan yang diperoleh hanya sebesar Rp. 385.843.497.142 artinya walaupun biaya pemeliharaan yang dilakukan besar tetap tidak berhubungan 
dengan pendapatan. Dapat dilihat juga pada tahun 2011 biaya pemeliharaan yang dilakukan terbilang cukup kecil yaitu sebesar Rp. 96.389.317,20 namun pendapatan yang diperoleh terbilang cukup besar yaitu sebesar Rp 1.091.844.096.163 artinya walaupun tinggi rendahnya biaya pemeliharaan yang dilakukan tetap tidak berhubungan dengan pendapatan. Biaya pemeliharaan secara teori yang harus

diperhatikan didalam mewujudkan aktivitas pengeluaran yang efektif yaitu : 1). menciptakan kondisi dimana setiap organisasi sadar akan kebutuhan untuk menggendalikan anggaran. 2). Monitor secara cermat pengeluaran Maintenance, seiring dengan tahun fiskal berjalan, review status dari komitmen anggaran dan pengeluaran dalam interval yang teratur. 3). Tangani masalah dengan efektif, tanggung jawab dalam mengendalikan anggaran manajemen harus tetap mencermati perkembangan maintenance tersebut.

\section{Hubungan Harga Jual dengan pendapatan}

Pada tabel 3 menunjukkan bahwa harga jual mempunyai hubungan positif dengan pendapatan di PT. Perindustrian dan Perdagangan Lembah Karet.

Harga jual adalah besarnya harga yang akan dibebankan kepada konsumen yang diperoleh atau dihitung dari biaya produksi di tambah biaya nonproduksi dan laba yang diharapkan (Mulyadi, 2005). Perusahaan biasanya berupaya menentukan harga yang akan memaksimalisasi nilai perusahaan. Harga yang ditentukan untuk sebuah produk akan mempengaruhi pendapatan perusahaan dan pada akhir keuntungannya. Harga jual sangat berhubungan dengan pendapatan, karena harga jual yang ditetapkan perusahaan terhadap produk yang dijual akan memberikan pendapatan atau keuntungan kepada perusahaan, maka harga jual mempunyai peran yang penting didalam perusahaan dan menentukan tinggi atau rendahnya pendapatan suatu perusahaan.

Harga jual yang telah ditentukan perusahaan di PT. Perindustrian dan Perdangan Lembah Karet berdasarkan harga Dollar Amerika Serikat, semakin tinggi nilai Dollar maka akan menambah pendapatan perusahaan. PT. Perindustrian dan Perdagangan Lembah Karet melakukan export karet ke sejumlah Negara yaitu Amerika Serikat, Cina, Jepang, Korea, dan India.

Hal ini terbukti pada PT. perindustrian dan Perdagangan Lembah Karet dilihat pada tahun 2010 harga jualnya yaitu sebesar Rp. 36.910,06 pendapatan yang diperoleh yaitu sebesar Rp. 851.552.313.268. peningkatan ini jauh meningkat dari pada tahun sebelumnya dimana pada tahun 2009 harga jualnya yaitu sebesar Rp. 22.177,59 namun pendapatan yang diperoleh juga kecil yaitu sebesar Rp. 385.843.497.142 artinya semakin tinggi harga jual yang diberikan maka semakin tinggi pula pendapatan yang diterima. 


\section{Simpulan}

Berdasarkan pada penelitian yang telah dilakukan di PT. Perindustrian dan Perdagangan Lembah Karet Padang, maka untuk menjawab identifikasi masalah penulis mengambil beberapa kesimpulan sebagai berikut :

1. Biaya pemeliharaan tidak mempunyai hubungan dengan pendapatan di PT Perindustrian dan Perdagangan Lembah Karet.

2. Harga jual mempunyai hubungan positif dengan pendapatan di PT. Perindustrian dan Perdagangan Lembah Karet.

\section{Saran}

Berdasarkan hasil penelitian, maka penulis menyatakan saran yangdiharapkan dapat menjadi masukan yang berguna bagi pihak-pihak yang berkepentingan

a. Bagi perusahaan

Perusahaan harus memperhatikan penetapan harga jual.Karena penetapan harga jual sangat mempengaruhi pendapatan perusahaan. Karena apabila harga jual meningkat maka pendapatan juga akan meningkat.

b. Bagi peneliti selanjutnya

Guna menyempurnakan lagi penelitian selanjutnya, maka penelitian dapat dilakukan tidak hanya pada satu perusahaan saja tapi dapat pula pada banyak perusahaan atau mengganti metode penelitian serta bisa juga dengan menambah variabel penelitian yang mempengaruhi pendapatan seperti modal kerja, biaya produksi dan biaya pemasaran.

\section{UCAPAN TERIMA KASIH}

Terima kasih peneliti sampaikan kepada:

1. Bapak Febryandhie Ananda, SE, M.Si selaku ketua STIE"KBP” Padang yang telah memberikan fasilitas dan kemudahan kepada penulis sehingga studinya dapat berjalan dengan lancer.

2. Ibu Lidya Martha, SE, MM selaku wakil ketua STIE"KBP" Padang.

3. Ibu Afriyeni, SE, MM selaku direktur AKBP Padang.

4. Ibu Dewi Zulfia, SE,MM selaku ketua Program Studi Akuntansi Sekolah Tinggi Ilmu Ekonomi "Keuangan Perbankan Pembangunan" Padang.

5. Bapak Muhammad Rivandi, SE, MM selaku Dosen Pembimbing penulis, yang telah membimbing penulis dengan penuh kesabaran dari awal proposal sampai saat sekarang ini

6. Ibu Lisa Amelia Herman, SE, M.Si selaku Dosen Pembimbing Akademik.

7. PT. Perindustrian dan Perdaganagn Lembah Karet Padang yang telah berkenan membantu dengan memberikan data laporan keuangan dalam penelitian ini.

8. Semua pihak yang telah memberikan dukungan beserta bantuannya dalam menyelesaikan skripsi ini. 


\section{DAFTAR PUSTAKA}

Crisdandi, P. (2015). Pengaruh Biaya Pemeliharaan dan Harga Jual Terhadap Pendapatan Petani Cengkeh Di Desa Tirta Sari Pada Tahun 2014. Jurnal Pendidikan Ekonomi, 5(1), 1-11.

Djuniadi, Afiffudin, M., \& Lestari, W. (2016). Statistik Inferensial. Teori, Aplikasi dan Latihan Soal dengan SPSS. Semarang: Program Pascasarjana Universitas Negeri Semarang.

Fandy, T. (2005). Strategi Pemasaran. Yogyakarta: ANDI.

Kusnadi. (2000). Akuntansi Keuanngan Menengah (intermediate) (Prinsip, Prosedur, dan Metode). Malang: Universitas Brawijaya.

Mulyadi. (2005). Akuntansi Biaya (edisi 5). Yogyakarta: UPP STIM YPKN.

Nugraha, E. (2012). Pengaruh Biaya Pemiliharaan Terhadap Pendapatan Operasional (Studi Kasus pada Perusahaan Kayu Persada Kusen Tasikmalaya). Jurnal Ekonomi, 1-12.

Pahan. (2010). Managemen Agribisnis dari Hulu hingga Hilir. Jakarta: Penebar Swadaya.

Panggabean, R. M., Sihombing, L., \& Salmiah. (2011). Analisis Pengaruh Biaya pemeliharaan terhadap Pendapatan Agrisnis Kelapa Sawit. Universitas Sumatera Utara.

Rasyid, T., Kasim, S. N., \& Kurniawan, M. E. (2012). Pengaruh Harga Jual dan Volume Penjualan Terhadap Pendapatan Pedagang Pengumpul Ayam Potong. Universitas Hasanuddin, 1, 1-8.

Rumahorbo, L. I. (2006). TERHADAP PENDAPATAN OPERASIONAL RUMAH SAKIT ( Studi Kasus pada RSUD Kabupaten Sorong ) SKRIPSI. Skripsi Fakultas Ekonomi Universitas Widyatama, (November 2003), 2006.

Setiawan, F. D. (2008). Perawatan Mekanikal Mesin Produksi. Yogyakarta: Maximus.

Sugiyono. (2015). Statistika untuk Penelitian. Bandung: Alfabeta.

Suwardjono. (2010). Teori Akuntansi Perekayasaan Pelaporan Keuangan (Edisi keti). Yogyakarta: BPFE-Yogyakarta. 